\title{
“BLODET SUSER"
}

\author{
MELODRAMA OG EMOTIONER I \\ HERMAN BANGS "DE FIRE DJAEVLE" \\ “THE BLOOD RUSHES" \\ MELODRAMA AND EMOTIONS IN \\ HERMAN BANG'S “DE FIRE DJÆVLE”
}

\begin{abstract}
Starting from the melodramatic quality of some of Herman Bang's texts, the article tries to show its specific function through a reading of "De fire Djeevle". Applying some thoughts of current research on affectivity, it links the narrative expressions of strong emotions to contemporary discourses on trauma on the one hand, and energy and entropy on the other. Affects are shown to be unreliable signs of complex or even repressed phenomena; the story therefore advocates scepticism regarding language, which has an analogy in the silence of the four artistes. Their trapeze-act can be read as a poetological signal for the story itself: dramatic feelings issue from a self-discipline that withholds its repressed motivation.
\end{abstract}

KEYWORDS | "De fire Djcevle", Herman Bang, melodrama, emotions, emotion research, discourse, entropy, trauma.

Hvad læseren forbinder med tekster af Herman Bang, hvad man husker efter læsningen er f.eks. Katinka Bais ulykkelige kærlighed og hendes sørgelige død, Irene Holms emotionelle optræden som Fenella, Tines selvmord og den af krigen forvoldte fortvivlelse, Ida Brandts ydmygelse eller Franz Panders væmmelse og lede. Man husker de bangske karakterer ikke for det de har gjort, men for det de føler. Det er heller ikke historiernes gang eller stedsbeskrivelserne, som efterlader det største indtryk, det er de store emotioner, "strong emotions", 49 som Charles Darwin kaldte det, da han nogenlunde samtidig med Bang udforskede menneskelige affekter fra en naturvidenskabelig synsvinkel.

I litteraturhistorien figurerer Bang derimod som modernitetens repræsentant, som en objektiv og nyskabende iagttager af storbyen og det moderne liv, og fremfor alt som impressionistisk fortæller, der registrerer fænomenernes overflade og gengiver bevægelse som uro og som udtryk for den moderne verden. Der synes at 
være en vis modsigelse mellem læsernes umiddelbare indtryk og de stilistiske og modernitetsteoretiske overvejelser, som litteraturhistorien plejer at fremhæve. Man kan derfor spørge, om denne modsigelse skyldes ufuldstændige læsninger, kun delvis dækkende opfattelser af værket, eller om værket byder på virkemidler, som arbejder med og fremkalder ambivalenser. Denne tese er for nylig blevet fremsat af Peer E. Sørensen, som argumenterer for, at Bangs værk meget grundlæggende er præget af ambivalenser: mellem det dekadente og det vitale, mellem realisme og allegori og mellem det ironiske og det sentimentale. Det er netop moderniteten, der ifølge Sørensen forårsager disse ambivalenser, modernitetens illusionsverden virker på én gang tiltrækkende og frastødende. Sørensen tematiserer i denne sammenhæng Bangs tætte forhold til det melodramatiske. Han vier et helt kapitel til spørgsmålet om det patetiske og melodramatiske i Bangs tekstuelle univers og kalder endda visse tendenser for kitsch:

"Tragedien hører ikke hjemme i Bangs univers. Bangs verden er snarere en melodramatisk verden, og det, vi kalder tragisk, er bare melodramatiske attituder uden substans. Dem kan vi studere i deres mest ekstreme form i Mikael og De uden Fodreland fra begyndelsen af det tyvende århundrede, hvor han excellerer i kitsch'et melodramatik, men de findes allerede i de første tekster, hvor han endnu ikke har lært de at mestre de ironiske dækninger.” (Sørensen I84)

Diagnosen om Bangs melodramatiske tendens tjener dog ikke som en kritik eller nedværdigelse af forfatterens virkemidler, men melodramaet opfattes - jfr. Peter Brooks - som "det patetiske svar på en affortryllet verden. [...] Det er derfor", skriver Sørensen, "en reflekteret og ikke en naiv form." (Sørensen I89)50

Ved siden af de to nævnte sene romaner er det især nogle af novellerne, der betjener sig af det melodramatiske som virkemiddel. I det følgende vil jeg prøve at uddybe og videreføre tesen om ambivalenserne og melodramaets reflekterede brug ved en læsning af Bangs novelle "De fire Djævle". Novellen udkom i I89o i tidskrift København under titlen "Les quatre diables", i samme år publiceredes den også som lille selvstændig bogudgave. I udgaven fra I895 havde forfatteren foretaget en række ændringer og oversat titlen til dansk. ${ }^{\text {I }}$ Popularitet fik novellen, da den blev filmatiseret af Friedrich Wilhelm Murnau i 1928, først som stumfilm, der

49 Både i "The Descent of Man” (I859) og den mindre kendte "The Expression of Emotions in Man and Animals" (I872) har Darwin diskuteret de forskellige udtryksformer for affekter, specielt med henblik på deres arvelighed og deres universalitet.

50 Han henviser her til Brooks passim. I det omtalte kapitel støtter Sørensen sig for det meste til en analyse af "Irene Holm" og den mindre kendte roman "Fædra". Desuden inddrages korte omtaler af andre tekster, bl.a. fortællingen "De fire Djævle”, der dog ikke behandles udførligt af Sørensen.

5I Kommentatoren i den forholdvis nye udgave af Bangs samlede noveller skriver, at der foretoges forandringer i teksten i anden udgave fra I899, og titlen ændredes til dansk i 3. udgave fra 1906. Det passer ikke helt, da bogudgaven fra 1895 allerede har de nævnte ændringer og den danske titel. Se Bang, Noveller: "Textkommentar" 848. I det følgende henvises til denne udgave ved direkte angivelse af sidetallet efter citatet i artiklens fortløbende tekst. 
blev genudgivet som taleversion året efter. Filmen er desværre tabt, men plakater og fotografier er bevaret. Historien blev ganske betydeligt forandret, forhistorien blev stærkt idealiseret og slutningen lavet om til en happy ending. Den blev til ren melodrama, hvorimod novellen - det er min tese - tager det melodramatiske i brug for at fremstille og analysere de menneskelige emotioner.

\section{Litteraturvidenskabelig emotionsforskning}

At stærke emotionerne spiller en afgørende rolle i Bangs fortælling, er øjensynligt: Vi læser om Fritz Cecchis begær efter en rig kvinde, om hans længsel og raseri, om deres elskovsmøde og hans efterfølgende fortvivlse, om angst og ydmygelse, da han mister evnen til at koncentrere sig om sit arbejde, og om hans tanker om gengældelse og hævn. Vi læser også om hans partner Aimées skinsyge, om hendes fortvivlede kval, som leder til dødelige konsekvenser. Men vi læser derudover om akrobaternes leg med emotioner, deres evne til at fremkalde angst, skræk og emotionel spænding. Hele historien er bygget på store følelser og affekter; det er netop et emne, som en fremtrædende aktuel forskningsretning i Tyskland beskæftiger sig med. Det drejer sig ikke bare om psykologisk, biologisk og kognitionsvidenskabelig forskning, hvor man traditionelt undersøger affekternes opståen og virkning, men også om forsøget på at forbinde litteratur- og kulturvidenskabelig forskning med naturvidenskabelige indfaldsvinkler og metoder og om at historisere grundlæggende antropologiske karakterstika. ${ }^{22}$ Thomas Anz har endda talt om et paradigmeskift og udråbt "an emotional turn", som beskæftiger kunst- og filmvidenskab og som vil rehablitere spørgsmålet om emotionelle effekter i litteraturvidenskaben. Anz og andre vil genvurdere det noget forældede begreb "indfølelse" ("Einfühlung") og er interesseret i, hvad der sker ud over den rent kognitive forståelse, når en læser er konfronteret med en tekst, hvordan litterære værker frembringer affekter og hvordan emotioner skabes og transporteres fra forfatter til tekst og videre til læseren. Det er altså hovedsageligt en virkningsæstetisk interesse, der fokusserer på læserens emotioner, som dog er frembragt af bestemte tekstuelle strategier og koder.53

Mere indviklet bliver det, når man beskæftiger sig med den narrative præsenta-

52 Den mest omfattende forskningsindsats udgår fra Freie Universität Berlin, hvor der i forbindelse med den tyske forbundsregeringens excellence-initiativ blev grundlagt et excellence-cluster om "Languages of emotion", som vil udforske interdependensen mellem sprog og andre tegnsystemer og affekter. De går ud fra - og jeg citerer fra deres hjemmeside - at "evolutionen i menneskets evne til symboliseringer er blandt de primære faktorer, der fremmer udviklingen af menneskelig intelligens og kultur. Eftersom emotioner samtidig spiller en afgørende rolle for menneskelig interaktion, må man gå ud fra, at sproglige evner og emotionelle udtryk i mange henseender er knyttet til hinanden. Men der er ikke bare reale emotioner skal undersøges på empirisk vis. Der lægges også vægt på såkaldte "imaginære konstruktioner”, som f.eks. religion, teater, fiktion og litteratur. "Gruppen vil med hensyn til former og funktioner undersøge sådanne sammenhænge mellem emotioner, symbolsk praksis og imaginære (fiktive) fænomener.” Se: http://www.languages-of-emotion.de/en/about/ profile.html; II.8.20I0). Vedr. emotionernes historisering se f.eks. Benthien et al.

53 Se også: Mellmann; Meyer-Sickendiek; Winko. 
tion af ambivalente følelser. Mens emotioner, ifølge den finske filosof Mikko Salmela, udgør et subjektivt engagement $i$ verden, indeholder emotionelle ambivalenser en udfordring, de bidrager til at sætte spørgsmålstegn ved værdier og identiteter og til at revidere vedtagne normer. Den moderne litteratur deltager ikke blot i denne revision, men driver den også fremad. Det er netop det, Martin von Koppenfels bog om Immune Erzäbler, et studie om affekter, Flaubert og den moderne roman, er optaget af. Flauberts prosa er kendetegnet ved tekstuelle strategier, som ikke inviterer til indfølelse, men hvor tværtimod "den identifikatorisk virkemåde er sat ud af kraft" (Koppenfels I9). Den moderne prosa genererer altså en emotionel reaktion ved at skildre følelsernes fravær eller deres umulighed, dens affektpolitik er ambivalent eller paradox. Emotionelle effekter opnås gennem "affektfornægtende gestus" (Koppenfels I8). Mest kendt er den stilistiske omsætning i Flaubert Impassibilité. Flaubert og andre moderne fortællere opererer altså med en æstetisk distance, de prøver at immunisere teksten og dermed læseren mod klischeerens magt og mod dybe følelser. Emotioner markeres som problematiske, de er instabile, ikke umiddelbare, men effekter af komplekse drifter og driftforskydninger. Mens den traditionelle episke fortællemåde bygger på vedvarende og stabile emotioner, på topoi som "troskab og hævnakter" (Koppenfels 28), som von Koppenfels kalder det, er Flauberts tekster karakteriseret ved "affektiv upålidelighed" (Koppenfels 39). Modsat Balzac arbejder han med en anti-dramatisk lammelse af handlingen og med anti-katarsis. Fortællerens perspektiv beskrives som et lægeblik, han er en immun iagttager, man kan tale om en kirurgisk skrivemåde. (Koppenfels 33)

\section{"De fire Djecvle": Blodet suser}

I en sammenligning med Flaubert må det følelsmæssige arsenal af skinsyge, had, fortvivlelse og raseri, som vi finder i Bangs "De fire Djævle", mistænkes for at være umoderne eller epigonal kitsch. Peer E. Sørensen har gjort opmærksom på, at Bang faktisk havde alvorlige forbehold over for Flaubert, idet han distancerede sig fra dennes æsteticistiske tendenser: "Bang er snarere bundet til en melodramatisk ekspressivitet med Balzac og det andet Kejserdømme som forudsætning" (Sørensen 9I). Spørgsmålet er, om dette udsagn, som placerer forfatteren i relation til hvad han har læst og er blevet påvirket af, også gælder Bangs affekt-fremstilling. Kan det være rigtigt, at han holder fast ved de traditionelle episke normer om "troskab og hævn"? Kan det passe, at han nogenlunde samtidig med Sigmund Freuds udforskning af den menneskelige psyke og tidens intensive interesse for følelshæmmede dekadenter eller hysteriskernes emotionelle forskydninger satser på at tematisere stærke følelser, deres umiddelbare udtryk og og en uproblematisk fremstilling af dem? Eller kan vi også iagttage de bangske ambivalenser $i$ iscenesættelsen af emotionerne i hans værk?

Allerede handlingsopbygningen i "De fire Djævle" varsler om stærke følelser: Historien er centreret omkring et kærligheds- og en jalousiforløb, og den ender med et mord og et selvmord. Efter at den ene af kvinderne i artist-kvartetten 'De fire 
Djævle' har måttet opleve, at hendes trapezpartner er forelsket i en anden kvinde, styrter hun både sig selv og partneren i døden. Disse plotelementer har tydelige melodramatiske træk, som cirkusmiliøet bidrager til. Det er en demi-monde, en drømmeverden, hvis drømme fabrikeres af show og glitterstads som det guldstøv, der regner ned over fire artister, når deres nummer er endt:

"Og oppefra, fra Rotunden faldt der, mens Louise og Adolphe snurrede rundt som to ustandselige Hjul i deres Gynger, pludselig en Regn af glitrende Guld som en gylden Støvsky, der lysede og langsomt sank - gennem de elektriske Lampers blanke Strøm af hvidt.

Et $\mathrm{Nu}$ saae det ud, som om Djævlene fløj gennem en skinnende Stime af Guld, mens Støvet, der langsomt dalede, plettede deres Nøgenhed med tusinde Pailletter, der straalte. $(479-80){ }^{\prime 54}$

Inden for dette miljø udspiller katastrofen sig. Den begynder med med Fritz' forelskelse i en dame blandt publikum, som lige fra starten er præget af "en Slags fortvivlet Desperation": "Selve Tanke paa hende pinte hans sene Hjerne, der ikke var vant til at tænke”, kommenterer fortælleren. Da damen en aften ikke kommer til en forestilling "følte han en dump Harme, et brutalt, men stumt Raseri" (alle 484). Han bliver emotionelt fuldstændig afhængig af hende: "Timer lang”, hedder det i teksten, "laa han om Natten hen i stum Rasen. / Og hans Attraa voksede sig fortvivlet gridsk i hans [...] søvnløse Nætter” (484-485). Det drejer sig om en melodramatisk diskurs, som her benyttes for at beskrive protagonistens følelser, den fortsætter, da han lærer kvinden at kende og tilbringer en nat med hende. En alvidende fortæller præsenterer læseren for Fritz' emotioner, som føler "et dumpt Raseri" (504), bliver "overvældet af en frygtelig Lidelse" (506) og af "Fortvivlelsen" (508). Fortælleren ved, at "Ydmygelsen brændte i hans Sjæl som havde han en Vunde i sit Bryst" (509), den kender til "Blodets Sus [som] vilde sprænge hans angstfulde Hjerne" (508).

De nævnte passager indeholder kendte klischeer fra melodramaets verden: Lidelserne er frygtelige, blodet suser, ydmygelsen brænder, protagonisten bliver overvældet, hans hjerne bliver sprængt. Flere af udtrykkene gentages og forstærkes på den måde. Den melodramatiske diskurs gengives oven i købet i en auktorial fortællemåde, der påstår at have insigt i karakternes indre. Alt dette er totalt modsat Bangs impressionistiske teknik og hans kendte poetologiske overvejelser. 55 Hvorfor denne kitschede diskurs? Er der en modvægt, som forhindrer, at fortællingen som helhed bliver til ren melodrama, er der andet end blod, sved og tårer i denne fortælling?

54 Jørgen Dines Johansen, som har leveret den mest omfattende og meget overbevisende læsning af teksten, skriver, at "[i] denne første præsentation af 'Djævlenes' nummer er alle tekstens grundlæggende tematiske elementer manifesteret", og han henviser til den økonomiske tvang, den "kunstneriske præsentations seksuelle karakter" og "driftens skæbnekarakter". Se Dines Johansen 26o.

55 Se Bang, Realisme og Realister 3-I4 og “Impressionisme’. En lille Replik” 692-694. 


\section{Ambivalente folelser - ingen happy ending}

Allerede fortællingens åbningssekvens giver nogle henvisninger til, at det patetiske ikke er den eneste udtryksmåde, som teksten opererer med. Ganske vist er der lige fra begyndelsen tale om emotioner, om ophidselse og feber, som hjemsøger artisterne før deres optræden; de "vibrere[r] af Anspændelse" (478) og Aimée taler med "hivende Bryst" (479). Men den melodramatiske diskurs optræder kun på isolerede steder inden for en travlheds-scene fuld af bevægelse og løsrevne replikker, som vi kender den fra andre Bang-tekster som Stuk eller åbingsscenen i Ved Vejen. Situationen begynder in medias res, fortælleren er for det meste registrerende og beskriver de ydre, de synlige indtryk, cirkusverdenen og artisternes trapez-nummer præsenteres på en scenisk måde. En anden modvægt til følelserne patos udgøres af modsætningen mellem det sløve publikum og artisternes anspændelse, travlhed og nervøsitet. Tilskuerne indtager kun langsomt deres pladser, til sidst kommer "de sløve Folk i Logerne [...] til Ro" (477). Dermed dannes der en ramme omkring de febrilske aktiviteter. Artisternes emotionelle anspændelse, som viser "Sjælen [...] i deres Øjne" (479), konfronteres med en verden udenfor. Denne modsætning understreges med betegnelsen 'at arbejde', som hele teksten igennem bliver brugt til at betegne de akrobatiske øvelser. Frembringelsen af kunststykkerne står på den måde i et modsætningsforhold til deres effekt: Der må arbejdes for at opnå akrobaternes leg og den fortryllelse, de prøver at opnå. Den ønskede effekt understreges af belysning, kostumer og guldpailletterne, og af et musikstykke, som altid spilles under trapeznummeret og som betegnes som en "Kærlighedvals". Da dens første strofe citeres første gang i teksten, står den umiddelbart efter ordet "arbejde" (477). Indgangsscenen udfolder altså et modsætningsfyldt indtryk: publikummets sløvhed og artisternes anspændelse, arbejde og kærlighedsvalsen, patos og nøgtern beskrivelse. Da scenen som helhed danner en ramme omkring det efterfølgende kærlighedsdrama, kan man formode, at dens ambivalenser også er af betydning for det følgende.

Hvilken funktion har da de nævnte ambivalenser mellem scenisk fortælling og eksalterede klicheer? Er den melodramatiske diskurs en betydningsbærende del af fortællingen? Der findes mindst tre svar på dette sprørgsmål, som kun tilsammen kan give en udtømmende forklaring og som skal udredes i det følgende. For det første bliver historien som helhed ikke til melodrama, fordi alle de nævnte stærke emotioner har udpræget negative konsekvenser. Attråen til den rige dame fører ikke til en happy ending, men til død og katastrofe. Alle de skildrede følelser er destruktive, der findes ingen glæde, latter, medlidenhed eller empati. Ordet kærlighed nævnes kun i operettesangen, som spilles under artisternes show. Fritz' følelser beskrives med ord som harme, raseri, fortvivlelse; han beruses, han ryster, har angst, vil hævne sig. Allerede da han første gang møder den elskede dame, er hans følelser af blandet, ja af negativ art: 
"Og da han i sin Staldmesteruniform siden kom ud i Stalden og saae hende, stod
han atter stum og fjendtlig og betragtede hende hadsk med det samme Blik, der
ikke turde se hende ret i Øjnene.
Men efter Forestillingen, inde i Restauranten, blev han pludselig atter overgiven,
næsten vild. Han lo, og han gjorde Kunstner." (485)

Kærligheden beskrives altså - og det har alle fortolkere af fortællingen været enige $\mathrm{om}^{56}$ - som drift, som et ukontrollerbart fænomen med negative følger. Denne emotion, som lånes fra en melodramatisk diskurs, belægges med negativitet og håbløshed. Modsat det konventionelle melodrama når Bangs fortælling ikke frem til at finde en mening i verden eller håb gennem kærligheden - drømmen om lykken negeres på den mest brutale måde. Hele plottet omkring Fritz og damen er ikke en kærlighedshistorie, men en historie om drift og begær, som udspilles - ikke kun omkring rent fysiske behov - men fremfor alt omkring sociale forskelle og social misundelse. I den største del af kapitlet om elskovsmødet mellem de to reflekterer Fritz over de fremmede omgivelser i det rige hus, om familiepotrætterne,57 som står for familiens betydning og status, og over sin egen identitet inden for denne fremmede verden: "saa var det virkelig ham Fritz Schmidt fra den Frankfurter Smøge, han, Drengen uden Fa'er, hvis Mo'er sprang i Floden en Dag, da hun var drukken, og hvis Mo'rmo'r havde solgt ham - ham og Broderen - for tyve Mark ...” (498). Hvad der lægges vægt på, er den sociale forskel, damens fine hænder og rige stoffer, familiens berømte navne og rummets luksus: "Alt var ham et Under" (499). Men her går det ikke som i eventyret eller melodramaet, hvor den fattige dreng bliver elsket af eller endda gift med prinsessen. Den sociale afstand fremkalder spørgsmål og identitetstvivl. For at fremhæve det umulige i forbindelsen, er forfatteren nødt til at præsentere os for den mandlige karakters indre, kun en alvidende fortæller kan fremhæve det inkommensurable ved hans ord: "Ti som Herre følte han sig: hun var hans". (499) Det er netop melodramaets følelsesarsenal fortælleren her benytter sig af for at udtrykke Fritz' fuldstændigt urealistiske affekt om beherskelse og ejendom. For at markere afstanden og det umulige i forbindelsen, identificeres Fritz gennem sine outrerede emotioner med melodramaets verden, hvorimod damens følelser forbliver ukendte for læseren. Hendes eneste udsagn består i den otte gange gentagne sætning "Du dumme Mand" (500-50I) - et udsagn, som bekræftes af historiens gang, mens hans melodramatiske forhåbinger og følelser umuliggøres og nægtes.

56 Se f. eks. Sørensen 158; Dines Johansen 264 og passim; Grodal 378.

57 Se Schiedermair. 


\section{Det ydre og det indre: affekternes upålidelighed}

Men emotions-diskursen indtager alligevel for megen plads i narrationen til kun at nægtes eller latterliggøres. Den iscenesættes derudover for at udforske forbindelserne mellem affekternes motiver og deres ytringsformer. For at gøre det muligt at tale objektivt om den subjektive emotionelle kondition, bruger man ofte det $\mathrm{i}$ filosofi og psykologi vedtagne begreb affekt, som er en agitation af en sindstilstand, der har en motivation, en udtryksdimension og en kropslig dimension. At blive overrasket i en pinlig situation bevirker, at man skammer sig og rødmer; overraskelsen er motivationen, skammen er affekten og rødmen dens kropslige refleks. Herman Bang ser ud til at have været specielt interesseret $i$ at udforske dette samspil mellem emotionernes motiver, ytringsformer og virkninger. En fortælling om artister, som fremhæver deres kroppe og kropslige evner, synes at være velegnet til sådan et formål. Det er med deres kroppe akrobaterne arbejder og opnår effekter og fascination: Aimée betragter sin trapezpartner og ser "hans Nakke, der havde baaret hende, hans Arme, som havde fanget hende, hans Lænder, som hun havde omsluttet ...” (506). Lige fra historiens begyndelse bliver artisternes kroppe beskrevet og udstillede: Vi ser fremstrakte arme, trikot'er, som slasker om ben, vi ser muskler og fibre i deres kroppe, nøgne hofter, ben i luften, hvide og sorte kroppe. Og det er kroppen, som kan give tegn på deres emotionelle tilstand: den "vibrerede af Anspændelse” (478), eller den bliver slap, kraftløs og dorsk, som Fritz' muskler efter elskovsmødet (504-5). Flere gange tales der om feberen, der er symptom på anspændte følelser, på nervøsitet, jalousi eller på attrå. Også det allerede citerede udtryk "Blodets Sus” er en kropslig reaktion på emotionel spænding. Om Aimée hedder det, at hun bider sine tænder sammen "i et afmægtigt, et fortvivlet, et rent fysisk Raseri” (496), og hun bliver bleg (486), da hun føler uoverenstemmelse med Fritz. Senere løber tårerne ned ad hendes kinder (487). Fritz ryster og skælver (5II), bliver hed og sitrer (5I4), mens Aimées emotionelle tilstand ytrer sig i tiltagende kulde, ubevægelighed og forstenelse.

Interessant er det nu, at symptomerne og reaktionerne langtfra er entydige tegn. Det er ikke de vedtagne skemaer, som man kender fra melodramaets verden, hvor man kan være sikker på, hvad rødmen betyder og hvad en bleg kind eller en rysten vil sige os. I Bangs fortælling er affekternes tegn arbitrære, fortvivlelse kan fremkalde feber eller forstenelse, og attrå kan frembringe tilfredshed eller had. Specielt den meningsløse forelskelse, som dominerer Fritz' emotioner, frembringer modsigelsesfyldte reaktioner. Der er tale om en attråens fortvivlelse eller om en umotiveret skiften mellem had og overgiven vildhed. Tegnene er ikke til at stole på, affekterne er langtfra entydige: Ligesom hos Flaubert bliver også Bangs læser konfronteret med en "affektiv upålidelighed”. Det var et vigtigt emne i tidens psykologiske forskning at udrede sammenhængen mellem det ydre og det indre, mellem kroppen og sjælen, mellem det fysiske og det psykiske. Fremfor alt tyskeren Wilhelm Wundt (I832-I920) er en af det 19. århundredes fremtrædende affektforskere, der prøvede at udforske disse sammenhænge. En af hans grundlæg- 
gende teser er, at man kan gå ud fra en tæt sammenhæng, sålænge der er tale om enkle former for perception og motorisk handlen, men at der i forbindelse med komplekse psykiske tilstande ikke kan kostateres nogen entydige relationer. Hans bog Grundriß der Psychologie, hvor bl.a disse ideer drøftes, udkom i I896, nogenlunde samtidig med at Bang bestræber sig på en narrativ beskrivelse af de intrikate relationer mellem psykiske og fysiske fænomener, mellem det ydre og det indre.

\section{Kraftdiskursens negation}

I denne sammenhæng skelner Wundt mellem såkaldte stheniske affekter, som er præget af kroppens anspændelse, og astheniske affekter, der viser sig som kraftesløshed eller slaphed, en forskel, som også figurerer i Bangs fortælling. Specielt kapitel V om Fritz' slappe og kraftløse krop efter elskovsnatten og hans desperate forsøg på at træne den og vinde sin vante styrke tilbage, berører en central diskurs i tiden, som betegnes med ordet kraft eller også med begrebet entropi. Ikke bare i dekadencen på den ene og vitalismen på den anden side, men meget udbredt $\mathrm{i}$ tiden før og omkring 1900 herskede der en frygt for at tabe livskraft. Tanken om kraftløshed var generelt meget udbredt. Specielt efter Rudolf Clausius i I865 formulerde begrebet 'entropi' var der fundet en diskurs, som blev brugt og som havde betydning i mange forskellige kulturelle og psykologiske sammenhænge..$^{8}$ Begrebet dannede grundlag for termodynamikken, hvis anden hovedsætning 59 omkring I90o blev overført på det kulturelle felt og på menneskelige følelser. Man følte, at man var havnet $i$ en tilstand af kraftløshed, man var bange for energitab, man så den samtidige kultur som et lukket system uden tilførsel af ny energi.60 Også Bangs fortælling henviser til tidens kraftdiskurs, den giver i historien om Fritz et anskueligt eksempel på frygten for tab af styrke og oversætter den i kropslige fænomener, så den samtidig berører tidens livlige psykologiske interesse, som netop er ved at etablere sig som en ny videnskab. ${ }^{6 r}$

Eftersom den første del af fortællingen hovedsageligt beskæftiger sig med Fritz' emotioner og alluderer til tidens affekt- og kraftdiskurs, skulle man forvente, at det er Fritz' kraftløsed, som også bestemmer historiens udgang. Hvad plottet indtil det femte af de ni kapitler lægger op til, er en katastrofe som følge af Fritz' utroskab og tab af styrke og kraft. Men denne forventning, som ville indløses i en simpel melodramatisk fortælling, indfries ikke. Handlingsgangens dramatik overtages af en

58 Se f.eks. Brandstetter. I dag bliver begrebet anvendt inden for forskellige felter som informationsteknologi, fysik og biologi for at beskrive fænomener vedrørende energiudveksling og energitab.

59 "Legemer, der befinder sig i et lukket system, hvor der ikke tilføres energi, vil søge mod større og større uorden."

6o Den paradigmatiske danske tekst, som er skrevet omkring denne livsfølelse og frygt for en entropisk tilstand, er efter min mening Jens Peter Jacobsens Niels Lyhne fra I88o.

6I Vi har her altså endnu et eksempel, som bekræfter Peer E. Sørensens tese om, at Bangs realisme er en diskursmimesis. Se Sørensen 44. Han gør forøvrigt også opmærksom på kraftdiskursens betydning. Se ibid.I94. 
parallelhandling omkring Aimées emotioner. Dermed negeres også kraftdiskursens betydning. At afbryde den forventede handlingslinje er en strategi, som forhindrer indfølelse og identifikation. Ikke bare Flauberts impassibilité er, som Koppenfels skriver, egnet til at sætte "enhver identifikatoriske virkemåde ud af kraft" (Koppenfels I9), også en overdreven, men eksplicit håbløs og afbrudt melodramatisk diskurs kan irritere læseren. Vi forlader altså Fritz' bekymringer om sin elskede og sin krop og følger hans partners emotioner. I fortællingen anden del er det Aimées skinsyge, hendes stumme "Kval" (506) og tiltagende lammelse, som bliver dominerende og aktivt fremkalder katastrofen og de to dødsfald. Hendes indre hensygnen og emotionelle død overføres på den måde til realiteten. Hun bliver i handlingens forløb mere og mere stille, ubevægelig, forstenet, til sidst en skygge. I den forstand er dødsspringet et forsøg på at omsætte hendes indre, hendes emotionelle tilstand. Det er et billede på det at nå til overensstemmelse mellem psyken og den fysiske realitet. Da Fritz nu er død for hende, ser hun hans krop som død i en vision, der anticiperer hendes gerning og historiens slutning:

"Den spillende Krop, det bevægede Bryst, den aandende Mund, Aarerne, som bankede varmt - det kunde blive stille og koldt.

Stille og ganske koldt.

De springende Muskler; Hænderne som greb hende; Nakken, hvor Livet sad skulde blive stille og koldt.

Armene ubevægelige og Musklerne som Sten og Panden kold, Halsen død, Brystet højt og stille.

Og Haanden, naar den løftedes, faldt saa tungt.

Arme og Ben og Haand - dødt.” (513)

Mens fortællerens indblik i Fritz' indre frembragte lidenskab og patos, viser fokaliseringen på Aimée endnu stærkere følelser med destruktive konsekvenser: hun er "som en morfingal", "som en sindssyg" og "[h]un fik Monomanens Ihærdighed" (5I4). Igen trækker en alvidende fortæller på melodramatiske ressourcer, som intensiveres gennem et moment af spænding. Begge vores protagonister fremstilles som styret udelukkende af deres emotioner; der mangler en rationel diskurs i fortællingen. Det er i denne ensidighed, i monomanien, faren ligger.

\section{Den traumatiske barndom eller emotionernes tidsliggørelse}

Men uden at fortælleren eksplicit tematiserer det, lægges der op til begrundelser for de stærke emotionelle reaktioner i et element af plottet, som endnu ikke har været omtalt. Uden for melodramaets verden af drift, skinsyge, feber og fortvivlelse, ligger der en historie, som forklarer fraværet af en mere moderat diskurs og af rationelle handlingsmåder, der kunne have forhindret katastrofen. Fortællingens tredje kapitel præsenterer et tilbageblik, som udreder de to søskendepars historie, deres triste, forældreløse opvækst, deres ubarmhjertige artist-træning, deres fysiske 
og psykiske lidelser i barndommen. Som børn blev de solgt til en cirkusagent, der behandlede dem som dyr; da deres kroppe bliver mishandlet, beskytter de deres psyke ved at blive til "Voksfigurer" (490), til tavse, ubevægelige pligtmennesker. Som højdepunktet for deres lidelser fortælles der om en umenneskelig træning, som Fritz må udføre for at øve jockeyspringet. Drengen hulker og bløder og græder og dirrer af smerte, øvelsen munder ud i at "Fritz' Legeme [kun] var [..] én Vunde.” (49I)

Det græske ord for vunde eller sår er trauma, og hele kapitlet beskriver det vi i dag forstår ved traumatiske barndomsoplevelser, som kan dominere hele det efterfølgende liv. Men deres traumatiske karakter implicerer også, at deres betydning forbliver ubevidst, at de efterfølgende virkninger ikke af personerne selv kan føres tilbage til de traumtiske, dvs. fortrængte hændelser. I Bangs historie er opvæksten gengivet som Aimées erindring, men hun husker kun, hvad der sker med Fritz, hun minder ikke sine egne sår. Hendes smerte forskydes til ham, den datidige krænkelse genoplives i nutidige emotioner, hvis overdrevne reaktion - det drejer sig trods alt kun om en banal og oven i købet håbløs utroskab - er begrundet i krænkelser, som ligger langt tilbage i tiden og som har frembragt en overfølsom psykisk struktur.

Traumabegrebet bliver brugt af Sigmund Freud i den i den tidlige udviklingsfase af hans psykoanalytiske teori - dvs. i I890'erne, ${ }^{62}$ da han skrev sine hysteristudier og samtidig med at Bang skrev sine noveller. Hans model af den mennesklige psyke går videre end Wilhelm Wundt og andre psykologer, da han koncentrerer sig om det underbevidste og det fortrængte. Han regner med patologiske reaktioner, med sygdomssymptomer som dengang blev kaldt hysteriske, når traumaer fra barndomstiden ikke bearbejdes og ikke gøres bevidst. I forsøget på at synliggøre menneskets indre går han altså endnu et skridt videre end den endnu unge psykologiske videnskab. Idet Bangs fortælling indføjer et tilbagebliks-kapitel, udgør den en parallel til udforskningen af psyken, som giver en indirekte begrundelse for protagonisternes intense emotioner. Dermed åbner den en op for en tanke, som langt overgår melodramaets emotionskoncept: Følelserne vises at have en historie. Ligesom i Freuds teori er de også i Bangs historie sedimenteret, men fortrængt erfaring. Her er ingen umiddelbarhed, som melodramaet opererer med, men en indirekte og for figurerne selv ikke bevidst tråd tilbage til fortidige krænkelser i barndommen. Læseren kan derimod forbinde de nutidige stærke følelser og deres katastrofale konsekvenser med de informationer, der gives i kapitel III, uden at fortælleren behøver at udtale dem direkte. Her indsætter Bang igen den tilbageholdne fortæller og gengiver følelserne "som i en Række af Spejle - deres Gerninger" Bang, "Impressionisme", 693), som han kalder det i sin poetik. Spejlene udgøres af nutidens melodrama og katastrofe. Hvad man kan se i dem og hvad der ikke bliver udtalt, er katastrofens fortrængte

62 Se Freud og Breuer. I de senere skrifter taber traumebegrebet sin betydning inden for Freuds psykoanalytiske teori. 
begrundelse. På denne indirekte måde afficeres læseren og forstår, hvorfor de melodramatiske emotioner opstår og fører til en katastrofe.

Kun i forbindelse med barndomskapitlet bliver den melodramatiske diskurs meningsfuld, den forklarer Fritz' attrå efter den fine dame, hans vilje til at eje hende og Aimées totale afhængighed af sin partner. I sammenhæng med kapitel III fremtræder de beskrevne emotioner som forskudte følelser, fortællingen bliver til et studie af emotionernes opståen og og i denne henseende minder Bangs fremstilling af affekterne om Flauberts. Ifølge von Koppenfels er det afgørende nye ved affektfremstillingen hos Freud, Flaubert og i det 20. århundredes moderne litteratur dens "tidsliggørelse" ("Verzeitlichung"; Koppenfels 58). Det er netop det, Bang opnår ved at give sine artister en historie.

\section{"Klovnernes melodi" - sprogskeptisk moddiskurs}

De stærke ord, som fortælleren benytter sig af for at skildre sine personers psykiske disposition, det kitschede sprog, har dog også en modvægt inden for fortællingen selv. Jeg har allerede antydet, at tekstens første kapitel stilistisk og fortælleteknisk adskiller sig fra den melodramatiske diskurs og danner en ramme omkring hændelserne, som genoptages ved fortællingens slutning. På impressionistisk vis udspares her selve katastrofen, Fritz falder som "en Sandsæk mod Manégens [sic] Jord" og Aimée "slap og skreg og styrtede". Så følger tre streger, et tomrum i teksten og så reaktionen: "Nu var der stille i Cirkus" (523). Ved det emotionelle højdepunkt mangler der ord, chokket gengives ved tankestreger. Resten af historien viser Louises, damens og de andre tilstedeværendes reaktioner ved ikke mindre end fem gange at afbryde iagttagelserne og antyde resten ved tre punkter. To gange sættes der tre længere streger for at markere en pause, en stilleståen, ordløshed. Og herefter fortsætter livet, ligesom i den berømte slutning i Ved Vejen; på vej hjem fra manègen nynner publikum kærlighedsvalsen, som afslutter fortællingen, før de allersidste ord lyder: "Det var netop den Aften meget livligt paa Markedet." (525)

I brugen af ordet "livlig" viser forfatterens ironi sig, og den afsluttende citering af kærlighedsvalsen er ligeså ironisk, ja, dens upassende brug antyder en grundlæggende mistro i sproget - og dermed også i den ordrige melodramatiske diskurs. Ikke mindre end I7 gange citeres denne strofe i udgaven fra I899 - i førsteudgaven fra I890 var det kun 7 gange, men Bang så åbenbart anledning til at gentage den flere gange som et ledemotiv i historien. Den banale strofe indeholder signalord fra operetteverdenen: "Amour, amour, / oh, bel oiseau, / chante, chante, / chante toujours." ${ }^{63}$ Det er oplagt, at også strofens brug er ironisk, ikke bare som afsluttende kommentar til katastrofen, men også som gennemgående tematisk kontrapunkt til Fritz' håbløse og Aimées fortvivlede kærlighed. Men den hyppige brug i fortællingen

63 Det er ikke lykkedes mig at verificere, om det drejer sig om et citat, men jeg anser det som sandsynligt, at Bang har opfundet ordene. 
viser ud over denne ironiske kommentar, at de samme ord kan betyde forskellige ting og at man ikke altid kan tro på sproget. De første tre gange citeres teksten som akkompagnement i manègen og illustrerer cirkussens illusionsverden, de næste gange udtrykker sangen Fritz' ligeså illusionære følelser for damen i logen. Da han kommer tilbage fra sin elskovsnat, synger han om "Amour, amour" og identificerer sig med sangens emotioner, mens læseren allerde her erkender hans fejltagelse. De sidste gange er sangen så blevet til ren spot og karikatur: Det er ved en fest før beneficeforstellingen:

"Inde i Restauranten steg Halløjet. De vrælte, de skreg og de lo. Det var Trip som begyndte at synge. Og pibende, fløjtende, kaglende faldt de Alle i; med Klowngrimacer, med Gebærder fra Manégen [sic], med vrængende Munde sang de: 'Amour, amour, / oh, bel oiseau, / chante, chante, / chante toujours.”' (520)

Her er kærlighedsvalsen blevet til "Klownernes Melodi”, artisterne er løsslupne, holder fest, drikker, leger, spiller, ler, råber og skriger. I Fritz’ øjne er de allesammen dyr, tåber, hyklere, han ser dem som "tykke Droner", deres larm opfatter han som "Iditotiens Triumfsang” (520). Her, kort før historiens slutning, er desillusionen komplet, sangens ord er meningsløse, de kan kun forstås som ironiske kommentarer, deres gentagelse efter ulykken bliver til ren sarkasme. Der er altså arbitrær sammenhæng mellem ordene og emotionerne, forfatteren benytter sangens forskellige anvendelse til at advare mod at tro på de pæne ord om følelser og kærlighed. Vi advares dermed også mod den melodramatiske diskurs, som bruges i tekstens centrale del, her bliver det klart, at teksten som helhed heller ikke tror på de store ord, som fortælleren har brugt for at berette om de outrerede følelser og deres opståen.

Som modvægt til melodramaets mange store ord finder vi artisternes tavshed. ${ }^{64}$ De fire artister bliver næsten ikke præsenteret gennem det de siger, deres dialoger består for det meste af udveksling af kommandoord, som "'En avant.' 'Ça va.' 'Encore" (494). De meget farlige øvelser indledes med "'En avant du courage' - 'enfin du courage."' (494; 523) Alle disse ytringer er gengivet på fransk, det fremmede sprog markerer afstanden mellem cirkusverdenen og realiteten, som omgiver den. Denne afstand markeres også, da artisterne indgående studerer de danske ord på plakaten, som annoncerer deres optræden. Specielt ordene "tegne vi ærbødigst" (5I7) ser fra deres franske og tyske baggrund mærkelige ud. De undrer sig over de fremmede bogstaver og de mærkværdige lyde: De gør "Nar ad Bogstaverne, ad Lydene” (517). Måske lyder ordet 'ærbødigst' for deres tyske ører som en ironisk kommentar til deres kunststykker, som udføres i luften og netop ikke har noget med 'Böden', med gulvene, at gøre. I hvert fald bidrager også denne episode til fortællingens sprogskeptiske udsagn.

Men for det meste tier de fire protagonister:

64 Også Dines Johansen har gjort opmærksom på protagonisternes tavshed og den sprogskeptiske tendens af teksten (Dines Johansen 277-279). 
"Efter Forestillingen samledes Truppen i Restauranten. 'Djævlene' sad, ved det samme Bord, alle fire tavse ligesom de andre. Ved et Par af Bordene begyndte man at spille Kort - bestandig uden at tale. Man hørte kun Pengenes Lyd, der blev skubbede hen over Bordet." (480)

De to søstre klæder sig af "uden Ord" (48I), på hjemvejen gik de fire "som sædvanlig tavse ved Siden af hinanden” (486), gang på gang beskrives deres samvær som tavshed og ordknaphed: "Ingen af dem talte, og stille satte de sig ved Restauranten vante Bord. Sejdlerne kom, og de drak i Tavshed.” (5I6). Deres ordløshed signalerer, at er de ikke i stand til at udtrykke det virkelig vigtige i deres liv: deres af traumatiske hændelser prægede følelser og deres indbyrdes afhængighed, som er betinget heraf. De er blevet vant til et samvær uden mange ord, hvilket fremmer deres arbejde, som kræver stille koncentration og ordløs overenstemmelse. Det vil sige, at artistverdenen kræver træning, håndværk og tysthed for at frembringe en illusion om lethed og leg, om skønhed og harmoni.

\section{Trapezkunst som poetologisk signal}

Denne illusionskunst svarer til Herman Bangs poetologiske principper. Ved at situere historien indenfor et artistmiliø, gengiver Bang et poetologisk billede på sin egen tekst. ${ }^{65}$ Ligesom på handlingsplanet er det ikke frem for alt kraft, det gælder, men den teknik, disciplin og tavshed, som gentagne gange beskrives som en maskinmæssig fremgangsmåde: "som en Maskines døde Hjul og Dele mødtes de, skiltes, mødtes igen.” (513) Stærke følelser er farlige i disse kunstneriske sammenhænge, der kræves tålmod, ro og overenstemmelse mellem kroppene. De fire artister har indtil nu været i stand til at sublimere deres fortrængte emotioner og har skabt deres trapezkunst som et surrogat for had, bitterhed og fortvivlelse. Ud af fortrængingen har de kreeret en illusionsverden, hvor "som om"-loven gælder. Lige fra første scene beskrives cirkusverdenen som en illusion, hvor de fire artister i deres kostumer ser ud, som om de var nøgne og hvor det virker "som om Djævlene fløj gennem en skinnende Stime af Guld” (480). Også artisternes illusion opererer med melodramatiske effekter, når de præsenterer hårdt arbejde som leg og disciplin som kærlighed:

"De naaede Trapezerne, og begyndte at arbejde. De syntes at flyve mellem de raslende Gynger, hvis Messingstænger lyste. De favnede hinanden, de fangede hinanden, de æggede hinanden ved Skrig; det var, som om de hvide og sorte Kroppe elksovsfuldt knyttedes sammen og løstes, knyttedes og løstes i en æggende Nøgen-

65 Dines Johansens analyse af fortællingens driftstrukturer munder også ud i en selvrefleksiv læsning. "'Les quatre diables", skriver han, "indeholder [...] en refleksion over betingelserne for at producere og konsumere kunst.” Når han fremhæver underholdning som "noget der har gyldighed for kunst i almindelighed”, altså både for cirkusartister og for forfatteren, peger han på en anden mulig grund for Bangs brug af den melodramatiske diskurs, som jeg ikke har diskuteret her (Dines Johansen 28I-282). 
hed. Mens Kærlighedsvalsen lød med sin søvnig smægtende Rytme, og Kvindernes Haar, naar de fløj gennem Luften, udslaaet, faldt flagrende ned om den sorte Blottelse - som en Atlaskeskaabe." (478)

De frembringer en illusion om kærlighed gennem træning og disciplin. Men da de stærke emotioner, da had og hævn og jalousi bryder ind i deres rutiner og indvirker på deres overenstemmelse i cirkuskuplen, fører de døden med sig. Cirkussen er en skinverden, dens præstationer og effekter bygger på fortrængte følelser og på nervepirrende illusioner, fordi publikums interesse og spænding i sidste ende fastholdes af, at det ubevidst tænker på døden, anelsen af katastrofen er altid til stede. Artisternes følelsløse verden danner på den ene side melodramets modsætning, på den anden side frembringer den en tilsvarende glitterverden af illusionære forhåbninger. Når vi betragter trapeznummeret som et poetologisk billede på Bangs egen teknik, så kan man slutte sig til, at også han som forfatter satser på teknisk præcision, disciplin og ordknaphed og prøver at afficere sine læsere ved at gengive illusioner, som ikke udtaler det vigtigste. De store ord, som bruges i denne fortælling, den melodramatiske diskurs, er derfor kun et middel til at karakterisere to personer for at udforske sammenhængen mellem det psykiske og det fysiske og for at præsentere et studie i emotionernes opståen. Som sådan er disse store ord ikke et mål i sig selv, men et middel inden for illusionernes verden, således som trapezkunsten og litteraturen også er det: De er spejle for fortrængte motivationer eller overførte emotioner, hvis egentlige herkomst og grund forbliver uudtalt. ${ }^{66}$ Her ligger altså sammenhængen mellem digterens midler og virkningen af hans tekster, som i det foreliggende tilfælde bliver tydeligt, fordi han i store dele af fortællingen afviger fra sin realistiske teknik og sin indirekte fremstillingsmåde. Men det læseren vil huske, er ikke de store ord om fortvivlelse, had og hævn, men den ordløse katastrofe og artisternes tavse og triste sammenhold, som er begrundet $\mathrm{i}$ traumatiske barndomsoplevelser.

\section{LITTERATURLISTE}

Anz, Thomas. "Emotional turn? Beobachtungen zur Gefühlsforschung". literaturkritik.de I2/2006.

Bang, Herman. "Lidt om dansk Realisme". Realisme og Realister. Portratstudier og Aforismer.

Kjøbenhavn, I879: 3-I4.

Bang, Herman. Noveller. København: Gyldendal, 2006.

Bang, Herman.”'Impressionisme'. En lille Replik”. Tilskueren. August I890: 692-694.

66 I Murnaus filmversion er det netop Bangs to vigtigste midler, nemlig tilbagebliks-kapitlet med baggrundhistorien om barndommens traumatiske oplevelser og den katastrofale slutning uden katarsis-tilbud, som fragtager melodramaet den ambivalens og den funktion, som præger den hos Bang. 
Benthien, Claudia, Anne Fleig og Ingrid Kasten (red.). Emotionalität. Zur Geschichte der Gefühle. Köln/ Weimar/Wien: Böhlau Verlag, 2000.

Brandstetter, Thomas (red.). Zeichen der Kraft. Wissensformationen I800-1900. Berlin: Kadmos, 2008.

Brooks, Peter. The Melodramatic Imagination. Balzac, Henry James, Melodrama and the Mode of Excess. New Haven: Yale UP, 1976.

Dines Johansen, Jørgen. “Den stiliserede drift eller kunstneren uden sikkerhedsnet”. Litteratur og begar. Ti studier $i$ dansk og norsk I80o-tals litteratur. Odense: Syddansk universitetsforlag, 2003: $247-284$.

Freud, Sigmund Freud og Josef Breuer. Studien über Hysterie. Einleitung von Stavros Mentzos. Frankfurt a.M.: Fischer, 1996 [I895].

Grodal, Torben Kragh. "Herman Bang”. Dansk Litteratur Historie. Red. Johan Fjord Jensen. 9 bd.,bd. 6, København: Gyldendal, 1985: 378 .

http://www.languages-of-emotion.de/en/about/profile.html; II.8.20Io).

Koppenfels, Martin von. Immune Erzäbler. Flaubert und die Affektpolitik des modernen Romans. München: Wilhelm Fink, 2007.

Mellmann, Katja. Emotionalisierung - Von der Nebenstundenpoesie zum Buch als Freund. Eine emotionspsychologische Analyse der Literatur der Aufklärungsepoche. Paderborn: Mentis Verlag, 2006.

Meyer-Sickendiek, Burkhardt. Affektpoetik. Eine Kulturgeschichte literarischer Emotionen. Würzburg: Königshausen \& Neumann, 2005.

Salmela, Mikko. "What is Emotional Authenticity?" Journal for the Theory of Social Behavior 35:3 (2005): 209-230.

Schiedermair, Joachim. "Problematisk likhet - Portretter som upålitelige bærere av identitet. Eksempler fra billedkunsten og litteraturen”. Edda 2 (2005): I66-I76.

Sørensen, Peer E. Vor tids temperament. Studier i Herman Bangs forfatterskab. København: Gyldendal, 2009.

Winko, Simone. Kodierte Gefüble. Zu einer Poetik der Emotionen in lyrischen und poetologischen Texten um 1900. Berlin: Schmidt Verlag, 2003.

Wundt, Wilhelm. Grundriß der Psychologie. Leipzig: Engelmann, I896. 